\title{
Biodiversity: function and assessment in agricultural areas. A review
}

\author{
Boris ClerguE ${ }^{a *}$, Bernard Amiaud ${ }^{\mathrm{a}}$, Frank PERVANCHON ${ }^{\mathrm{b}}$, Françoise LASSERRE-JOUlin ${ }^{\mathrm{a}}$, Sylvain PlantUReuX ${ }^{\mathrm{a}}$ \\ ${ }^{a}$ UMR INRA-ENSAIA-INPL, Agronomie et Environnement, 2 avenue de la Forêt de Haye, 54505 Vandoeuvre-lès-Nancy, France \\ ${ }^{\mathrm{b}}$ Trame, 9 rue de La Baume, 75008 Paris, France
}

(Received 25 October 2004; accepted 25 October 2004)

\begin{abstract}
Biodiversity has become a central concept in agronomical research since the Rio de Janeiro summit in 1992. Agricultural areas include a unique biological diversity which is the basis of human activities. Conservation of this biodiversity in agricultural and protected areas is therefore fundamental and requires an operational approach. Biodiversity is a complex entity which can be spread over several levels (genes, species, ecosystems and ecological processes) and can be related to three main functions: (i) patrimonial functions, (ii) agronomical functions and (iii) ecological functions. The patrimonial function concerns conservation of the landscape aesthetic and threatened species. The biodiversity function according to relationships with agricultural activities describes resistance to biotic and abiotic stress, and the production of cultivated ecosystems. Biodiversity is also involved in ecological functioning through the existence of special habitats with particular species The relevance of assessment tools is required in order to understand and evaluate the impact of farm practices on the different compartments of biodiversity on the patch scale to the landscape scale. Different methods, such as direct measurements with biodiversity indexes, biotic indicators and models are described and their suitability and limits are discussed.
\end{abstract}

biodiversity / assessment / landscape / indicators / sustainable agriculture

\section{INTRODUCTION}

Biodiversity has become a central concept in agronomical research since the Rio de Janeiro summit in 1992 [24]. This event indicated a world consciousness of the importance of biodiversity protection for sustainable development [14]. Biodiversity protection can be motivated by pragmatic reasons. For example, biodiversity represents a potential reserve of new compounds for medicine, interesting genes for plant breeding and services for agriculture $[2,37,102,105]$. Biodiversity is also considered as mankind's heritage and human beings cannot decide on the existence or not of a species [20].

Considering the role of agriculture in the preservation of biodiversity appears to be a key issue. For better biodiversity conservation on the large scale of territories, knowledge and creation of conservation tools are necessary not only in protected and restricted areas but also in agricultural areas. On the European Community scale, agricultural areas are more significant (44\%) than protected areas, which represent less than 5\% [114]. In addition, mosaic landscapes based on a mixture of agricultural and semi-natural areas represent a particular reserve of biodiversity. Finally, biodiversity preservation in agricultural lands produces new challenges: to conciliate production necessities with respect for the environment $[2,16,105$, 141]. Additional studies have been conducted in urban land- scapes [12, 74, 144], and in natural areas [10, 25, 75, 97, 103], but these specific cases will not be developed in this paper.

Protection of biodiversity requires assessment methods in order to understand disturbance effects on biodiversity, monitoring its state and the relevance of agri-environmental measures. However, biodiversity is a very complex entity with the interaction of different scales (species, community, ecosystem and landscape). Biodiversity is not only a concept which expresses the "variety of life" but is also a socio-political construction and an ecological measurable entity [44]. Thus, operational definitions of biodiversity are necessary to determine research directives, biological conservation measures and make environmental policies.

For instance, Noss [92] has described biodiversity by a hierarchic approach based on the distinction between "composition", "structure" and "function" applied on different scales (Fig. 1). The work of Noss has been a key reference in ecological studies for monitoring biodiversity. Biodiversity "composition" is an inventory of characteristics, such as biomass production, species abundance, presence of threatened species or habitat proportions. Biodiversity "structure" is the organisation of biodiversity components and the relations between them. These components take into account structural data about population (sex, ratio, morphological variability, etc.), habitat (slope, foliage density, etc.) and landscape (connectivity, fragmentation, patch size, etc.).

\footnotetext{
* Corresponding author: boris.clergue@ensaia.inpl-nancy.fr
} 


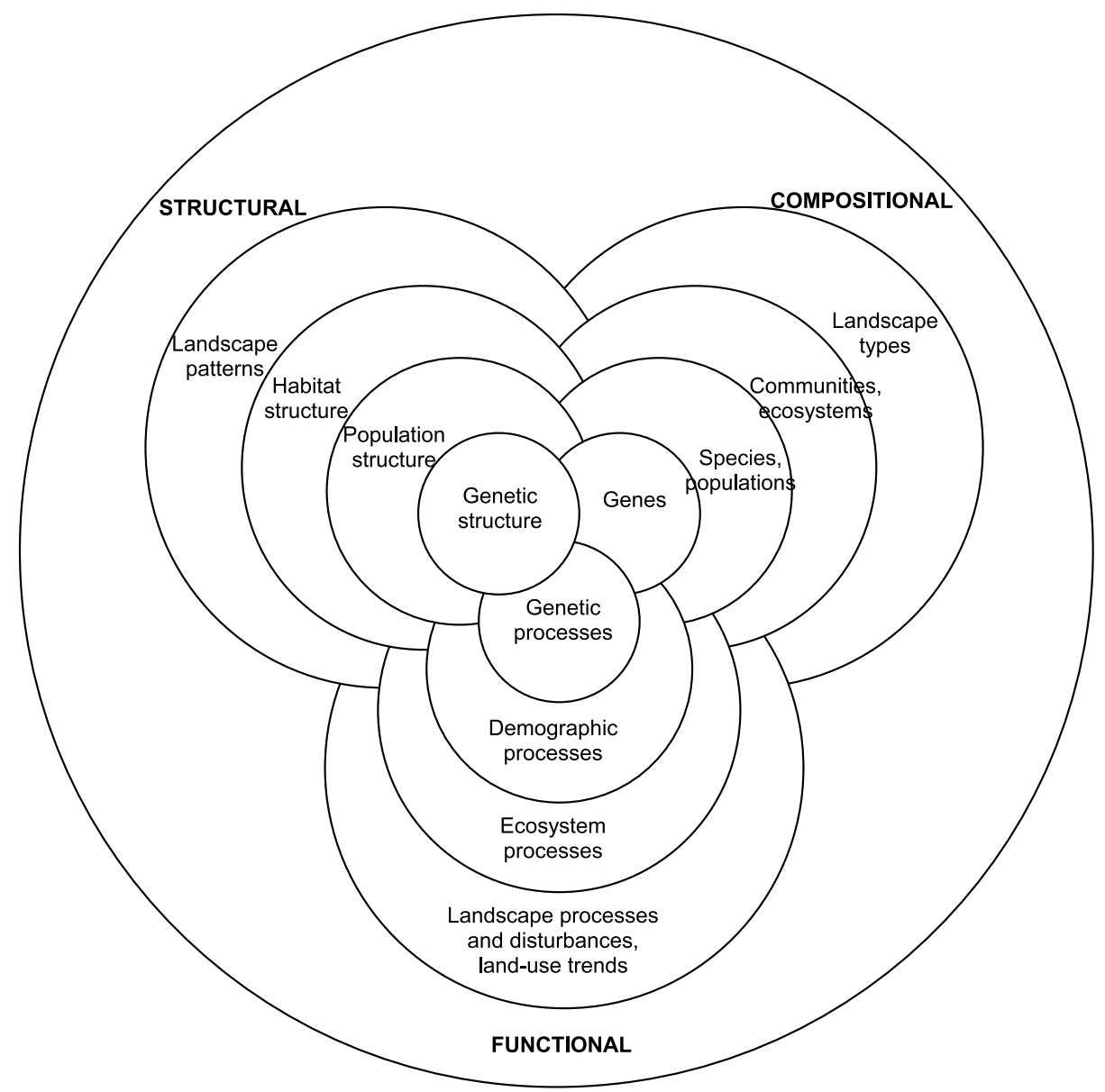

Figure 1. Compositional, structural and functional biodiversity, shown as interconnected spheres ([92] modified).

The third level, biodiversity "function", is the whole of particular ecological processes, such as demographic processes or population dynamics and genetics. The functional groups theory is another operational approach which links biodiversity to ecosystem processes. Each functional group is related to an ecosystem process such as organic matter decomposition or nitrogen mineralisation [71, 76, 78, 79, 137, 142]. An ecosystem process becomes an ecosystem service according to a human point of view. For example, biomass production of grassland ecosystem represents forage production for cattle. Ecosystem services therefore form a basis for human life [120].

Agricultural areas contain a unique and useful biodiversity which results from farm management. In order to promote sustainable agriculture, knowledge and conservation of biodiversity need clarification on two points: (i) the biodiversity concept, especially the integration of the benefits of biodiversity, and (ii) assessment methods used to evaluate and monitor biodiversity.

\section{BIODIVERSITY AS A MULTI-FUNCTION}

Biodiversity is a complex entity which can be spread over several levels. Authors have given, therefore, different ways to define biodiversity as a sum of several functions.
Noss [92] proposed a hierarchic approach involving the concept of the term "function" of biodiversity. He used it to define all the processes which occur on the different scales: gene, species-population, community-ecosystem and regional landscape (Fig. 1). Nutrient cycling and energy flow are especially taken into account. However, Noss has focused on the ecological functions of biodiversity.

On the contrary, Peeters et al. [106] have expressed biodiversity functions essentially according to relationships with agricultural activities. Biodiversity is split into three parts: (i) agricultural biodiversity, (ii) para-agricultural biodiversity, and (iii) extra-agricultural biodiversity. "Agricultural biodiversity" represents the variety of life directly used for farming production. It involves animal and plant species, races and varieties. "Para-agricultural biodiversity" (also called "functional biodiversity") is the variety of life indirectly used for farming production such as soil fauna, auxiliary fauna, pollinators, grassland plant diversity and more generally ecosystem services. "Extraagricultural biodiversity" represents biodiversity in production areas which does not contribute to production. These are mainly particular species, especially endangered species (orchids, butterflies, great mammals, etc.).

Gurr et al. [53] also reviewed benefits of biodiversity for agricultural production such as pest management which favours 

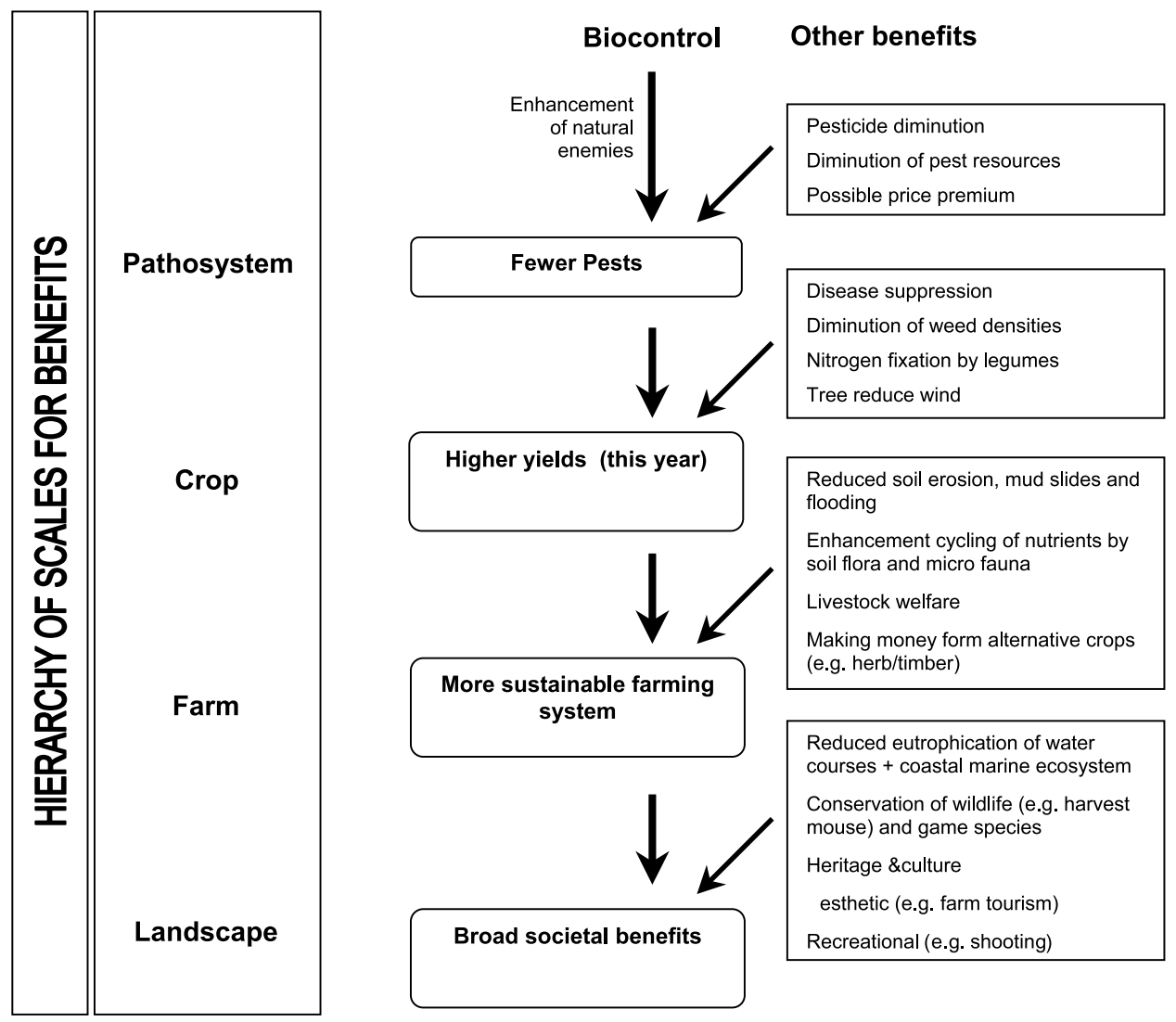

Figure 2. The hierarchy of scale for potential benefits of multi-functional agricultural biodiversity ([53] modified).

enhancement of natural enemies. They also proposed a hierarchy of biodiversity benefits based on the different scales of biodiversity. For instance, pest management is obtained on the patch scale by changing practices, and on the landscape scale by the integration of non-crop vegetation which increases diversity (Fig. 2).

The definitions of Peeters et al. [106] and Gurr et al. [53] show that agricultural activities are strongly linked to biodiversity components. Paoletti et al. [101, 102] previously highlighted, by an inventory of biodiversity components, that agricultural production is based on biodiversity.

Duelli and Obrist [37] have reviewed the different aspects of biodiversity with both an ecological approach and an agronomical approach. They separated these aspects into three parts which motivated preservation and studies on biodiversity: (i) conservation (threatened species protection), (ii) biological control (antagonist species diversity), and (iii) resilience (ecosystem processes). The Duelli and Obrist [37] approach presents a biodiversity concept which manages several functions or ecological services. The three parts may be, respectively, extended to three main functions: patrimonial functions, agronomical functions and ecological functions. The approach of Gurr et al. [53] highlights the necessity of taking into account the action of these functions on several scales.

\subsection{Patrimonial functions}

The biodiversity of a site is related to history, and thus constitutes a patrimony. This patrimony is a common heritage with both a natural or biological and cultural patrimony. More often than not, these two patrimonies are inter-related. Patrimonial functions are present on different scales: on a landscape scale, biodiversity contributes to aesthetic, and on a smaller scale, to particular habitat, species and a genetic patrimony.

\subsubsection{Aesthetic function}

Biodiversity contributes to the aesthetic value of the landscape; this is also called visual or scenic quality. On the landscape scale, patrimony therefore has an aesthetic function. The aesthetic function creates a feeling of identity for residents, and a recreation object for tourists.

For the European Landscape Convention [39], "landscape means an area as perceived by people, whose character is the result of the action and interaction of natural and/or human factors". Thus, the aesthetic value includes natural and cultural elements of the landscape. Steiner [133] stated that "usually, a landscape is that portion of land or territory which the eye can comprehend in a single view, including all its natural characteristics". 


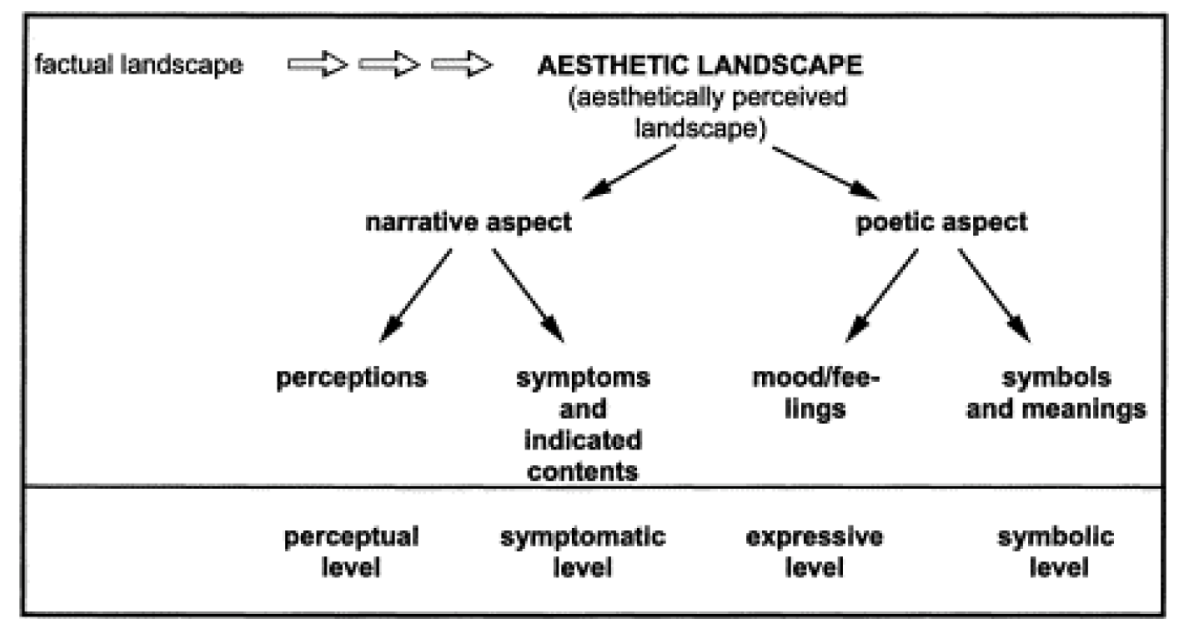

Figure 3. Aesthetic perception of landscape and levels of aesthetic cognition ([91] modified).

Aesthetic values result from the relationship between the landscape and an observer. Observation provokes in the observer a visual perception that is associated with thoughts and feelings. The NGO European Academy for the Culture of Landscape [112] attributed the first landscape description in Europe to the Italian poet Francesco Petrarca (1304-1374). At the "Mont Ventoux" summit (Vaucluse, France), Petrarca related an observation experiment. He observed a panorama, the nature which he perceived as a totality: a landscape. This observation is considered as an aesthetic perception. Nohl [91] explained precisely the aesthetic perception process (Fig. 3). He differentiated several levels of perception; especially between, on the one hand, results of observation and interpretation, and on the other hand, objective (narrative aspect) and subjective approaches (poetic aspect). However, Weinstoerffer and Girardin (2000) underlined that the first landscape studies which began in the seventies had used only an "objective pole" with a descriptive science. This point of view includes naturalistic approaches and agro-ecological approaches: the first approach studies landscape structure by inventories of the characteristics (vegetation, relief, soil, geology and climate), the second approach is a taking into account of agricultural and semi-natural elements [143]. Since the earlier work of Shafer et al. [122], more recent landscape studies have included both objective and subjective approaches (See, for example: $[5,11$, 13, 99, 100, 141]). Colquhun [27] and Bosshard [11] pointed out that subjective approaches have the same scientific rigour as the objective approaches. This conviction is based on the works of the German poet and scientist Goethe (1749-1832) in botany (Plant metamorphosis, 1789) and optics (Theory of colours, 1810). The American philosopher Emerson (18031882) also sustained this point of view, especially in his essay Nature (1836).

In addition, Schüpbach [121] underlined the fact that the tourist industry and landscape protection organisations (see, for example, [130]) use aesthetic perceptions in order to raise the public conscience of the landscape.
Analysis of these perceptions showed that humans have "a natural attraction for diversity which is a source of pleasure, satisfaction, or happiness" [143]. A preserved natural landscape provoked the same feelings [4, 99, 100].

Biodiversity gives origin to an aesthetic function on the landscape scale but Nohl [91] showed another complexity level: "If one compares the appearance of today's landscape with that of premodern and early modern time, one recognizes that the landscape did not only lose its wealth of elements but also its sense of unity which gave form to that variety". Landscape aesthetic is thus a result of the diversity of elements and their cohesion or organisation.

An agricultural landscape is a complex assemblage of agricultural, semi-natural and rural areas [114] and constitutes a mosaic of many elements. Heterogeneity is a parameter that helps with understanding the organisation of mosaic landscapes. Heterogeneity is the diversity of landscape elements (patches) and the complexity of their spatial relationships. Fragmentation and connectivity are measures that characterise landscape heterogeneity. Fragmentation gives information on the spatial organisation of a habitat by patch size, while connectivity describes the spatial relationships between patches [18]. These spatial parameters permit the understanding of the preferences of the observers.

A landscape can offer some aesthetic qualities to the inhabitant or tourist but landscapes contain other elements which the public prefer, and ecological characteristics. These elements also have a patrimonial value.

\subsubsection{Patrimonial function on other scales}

Biodiversity can also have a patrimonial interest that is more due to its historical and socio-cultural context than its visual quality. On small scales, patrimony includes habitats, species and genetic patrimony.

On the European scale, the Directive 92/43/EEC (Habitats Directive) on the conservation of natural habitats, wild fauna and flora has established the European ecological network Natura 2000. 
Natura 2000 aims to maintain vital elements of the natural patrimony. These natural areas are also related to economic activities (agro-forest production and rural tourism), hobbies (hunting, fishing, outdoor hobbies, etc.), and contribute to maintaining the quality of rural life.

Following the Convention on Biological Diversity the signatory states must contribute to species conservation: this is especially the case for threatened species [23] that belong to natural patrimony. Based on the Red list concept of the World Conservation Union (IUCN), threatened species are registered for particular areas.

So-called flagship species are used to increase public interest and attract funding for ecological matters [21]. These species are often threatened species. Flagship species can be a plant (orchids, etc.) or an animal (butterflies, eagle, bear, wolf, etc.) with sometimes a cynegetic value (partridge, hare, etc.). Flagship species belong, therefore, to cultural and natural patrimony.

Pervanchon [109], owing to a request from French Regional Natural Park managers, found that rarity characterises patrimonial value in permanent meadows. The rarity criteria of a species is based on the rarity index of Janssens [58]. Pervanchon [109] proposed a definition of a patrimonial species which covers the concepts of both flagship and threatened species. A patrimonial species is "a rare or threatened species which needs local management and which may be a flagship species and may have cultural importance" [109]. The Patrimoniality concept is used in ecological studies in this sense (see, for example $[43,70,104])$.

On the genetic scale, natural and agronomic species have a genetic patrimonial value. Genetic diversity allows species perenniality and species adaptation to environment changes. In addition, knowledge of genetic diversity gives measures for the breeding and conservation of plants [8] and animals [31]. This may also help in conservation of wild species and forest management [45]. Conservation of genetic resources has been committed internationally especially via the Global Programme for the Management of Farm Animal Genetic Resources (FAO) and the Global Plan of Action for the Conservation and Sustainable Utilisation of Plant Genetic Resources for Food and Agriculture (FAO, Leipzig, June 1996).

\subsection{Agronomical functions}

Agricultural production can be considered as linked to different biodiversity functions. This biodiversity may control crop and meadow stresses (pests, diseases, dryness, deficiencies, etc.) and support essential plant functions such as reproduction via pollinators. Biodiversity acts on agronomic parameters on different scales: on the patch scale, on the matrix scale, which includes semi-natural boundaries (bark, ditches and hedgerow), and on the landscape scale with hedgerow webs (connectivity and fragmentation) or forest areas.

\subsubsection{Biotic stress resistance}

\subsubsection{Pest control}

Biodiversity can control pest population by two mechanisms: on the one hand, floristic diversity implies a decrease in host species (bottom-up effect), while on the other hand, an increased diversity of predators controls pest populations ( topdown effect) [53].

Arthropods and birds are the main auxiliaries. The presence of these useful fauna is strong correlated with semi-natural areas [60, 62].

In the case of the vole, their outbreaks are strongly correlated with land cover. High values of the meadow/crop area ratio indicate a high risk of outbreaks [48]. Millan de la Peña et al. [84] showed that habitat diversity (connectivity vs openness) allowed a diversity of rodents and thus decreased the generalist species.

A high species diversity within a community enhances its resistance to invasion of alien species. The works of Levine et al. [73] and Shea and Chesson [124] reviewed the different studies examining this theory. The majority of studies were carried out on plants in grasslands. In addition, they indicated that the most diverse natural communities were the most frequently invaded.

\subsubsection{Disease and nematode control}

Crop protection against diseases is an important part of the farming budget. The diversity of plant and soil organisms may help to control pathogenic microorganisms, especially fungi [1, 117] and plant-parasitic nematodes [147]. In addition, disease control by biodiversity helps to reduce pesticide inputs. Crop rotation (diversity in time) and the diversity of organisms in organic amendments are management practices which increase soil biological activity. For example, wheat diseases can be reduced by cultivar blending [57], while compost amendment increases soil biological activity and controls turfgrass diseases [90].

The presence of hedgerows limits propagation of some diseases (e.g. Oidium) by reducing wind, but can induces other disease in shaded and wet areas.

\subsubsection{Abiotic stress resistance}

\subsubsection{Biodiversity benefits for soil properties}

Soil biota regulates many ecological processes: litter decomposition, nutrient cycling, pathogen control, mineral weathering, etc. From an agronomical point of view, the processes of decomposition, immobilisation and mineralisation liberate nutrient elements according to plant growth [102]. Thus, losses by leaching are limited as plants absorb necessary elements. Moreover, symbiotic associations with mycorhizal fungi increase nutrient availability, e.g. of phosphorus, and increase plant water uptake. Mycorhizal symbiosis is therefore important for plant growth. It is present in all plant species except in the Brassicaceae family [136]. Soil biota can also weather minerals by production of chelating agents and catalyses redox reactions [2].

The diversity of soil organisms and their abundance are involved with processes that affect soil structure. Crossley et al. [30] defined the influence of each organism category (microflora, microfauna, mesofauna and macrofauna) on each soil structure. These organisms act as much on particle aggregation and humification as porosity creation and organic-mineral phase melting. Soil structuring increases the growth of plant 


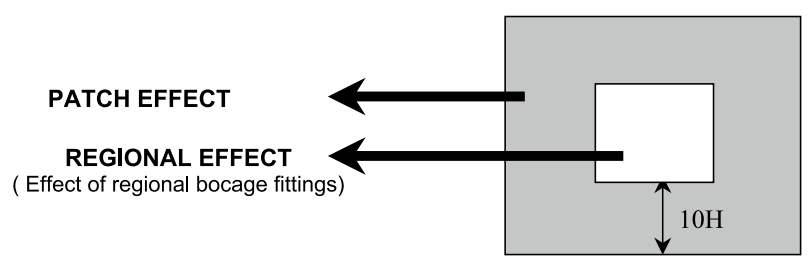

Figure 4. Duality effect in a bocage patch ([26] modified). With H: total height of bank and vegetation, about $10 \mathrm{~m}$ in the Western France bocage.

roots, anchorage and fluid circulation (air and soil solution). Soil structuring also increases penetration of rain water.

On the landscape scale, wind erosion is a soil quality matter often neglected. In open-field landscape without plant cover, a low-speed wind $\left(4 \mathrm{~m} \cdot \mathrm{s}^{-1}\right)$ may provoke soil erosion of small particles. Humus is mainly present in the soil upper layers and can be taken away by wind. The presence of hedgerow limits wind speed and thus soil erosion. The carbon value of hedgerow board soils is the highest [26]. The whole hedgerow/bank/ditch creates lateral discontinuity which limits water and particle lateral transfers. This process reduces soil erosion by hydric transfer due to, for example, superficial runoff and hypodermic flow. In the soils affected by this erosion, especially for sloped patches, soil is always deeper in bank uphill slopes than in downhill slopes [118]. Erosion modifies the quantity of the different soil elements (sand, silt and clay) which have consequences both on soil structure and fertility. Moreover, the presence of the whole hedgerow/bank/ditch allows a better infiltration and thus a greater water stock than in open-field landscape [118]. Diversity and organisation of landscape elements influence soil water availability, and thus plant growth and yield.

\subsubsection{Microclimate}

Microclimates are strongly connected to regional climate but they are also linked to local geomorphology (slope, aspect and relief which reduces winds) and human activities. The diversity of landscape elements, such as hedgerows, acts on climatic parameters (wind speed and Potential Evapo-Transpiration).

On the patch and regional scales, bocage structure decreases wind speed by about 30 to 50 per cent [26]. The effect of bocage on the patch microclimate is due to landscape structure both on the patch and regional scales (Fig. 4). This wind speed diminution decreases Potential Evapo-Transpiration by 4 to 6 per cent. Although several effects of bocage are known, effects on farm production are difficult to measure. In a bocage, the day air temperatures are higher and the night temperatures are lower in comparison with open areas.

In addition, pluviometry is higher in the presence of a hedgerow web than in forest areas [129].

\subsubsection{Pollination}

In addition to the domestic honeybee (Apis mellifera), pollination is done by a diversity of insects (bumblebees, wild bees, etc.). A high diversity of habitat increases the occupancy rate of bumblebees [7]. These pollinators are more efficient than the honeybee in unfavourable climatic conditions (cold and overcast sky). Pollination allows fecundation of entomophile plants, especially dicotyledonous plants [85]. For crop production such as rape or sunflower, pollination directly affects a yield component, the seed number. In grasslands, pollination allows reproduction of entomophile species. The consequences of pollination are that sexual reproduction maintains genetic diversity that vegetative reproduction cannot. This genetic diversity increases adaptation to environmental stress.

\subsubsection{Crop and animal production}

Regulation of biotic and abiotic stress and pollination are one of several agronomical functions of biodiversity. Aggregation of these functions gives biodiversity effects on crop production. However, other factors are linked to crop production. For example, the species forage value and species richness of a grassland is correlated to forage production. In addition, species diversity influences crop and forage production and also quality of dairy products (milk and cheese).

In the case of hedgerow effects on production components, effects must be seen on the patch and landscape scales. In a bocage grid, the culture response of hedgerow effects shows a spatial heterogeneity. For the climatic effect, the centre of the patch is controlled by regional context and the boundaries by local context (Fig. 2).

The presence of hedgerow also influences growth rhythms and yield. A spatial heterogeneity is observed for precocity and yield in strips which are perpendicular to dominant winds. Favourable areas spread on 2 to 6 times the hedgerow height.

On the landscape scale, bocage increases crop precocity in comparison with open areas. However, effects on yield are often contradictory because there is also an interaction between the plant cultivar and its area.

Protected Designation of Origin cheeses are characterised by typical sensory properties (taste, odour and texture). In order to understand links between cheese properties and a geographical area, a "Terroir", several chemical studies were carried out. These studies have demonstrated clearly that some odouractive compounds (aldehyde, ester and terpenoid compounds) found in grassland species can be transferred to the milk and cheese $[15,22,29,59,139]$. Dairy product quality is therefore related to floristic diversity. A diversity of these compounds is produced by plant species adapted to a particular habitat (high mountain pasture, extensive practices), especially dicotyledonous species such as Achillea sp., Meum sp., Thymus sp. or Geranium sp. [35, 82]. Odour-active compounds form a fingerprint of dairy products and may be used for traceability [139].

\subsection{Ecological functions}

According to Duelli and Obrist [37] biodiversity implied in ecological functioning is involved in some services for agricultural activities but diversity is also related to some ecological aspects. Biodiversity (i) creates typical habitats, (ii) includes particular species, and (iii) is related to ecosystem functioning. 


\subsubsection{Habitats}

Habitat is the place where an organism or population occurs naturally. The habitat of a (plant or animal) species is its "place of residence" [93], which means the area to which it is adapted and which it is able to occupy. A habitat type includes specific factors (ecological conditions) which allow the species to survive and to reproduce successfully. If the habitat quality changes (e.g. due to anthropogenic impact) or the ecological requirements of the species change, it is forced to retreat from its place of residence [17].

In addition, in agricultural areas, the presence of extensive practices allows formation of habitats with a specific biodiversity [19].

Abandonment of these practices causes species impoverishment. In order to prevent this phenomenon, Environmental Sensitive Areas (ESAs) have been established by the CAP (CE 797/85). European Directives Habitats (92/43/EEC) and Birds (79/409/EEC) allowed establishment of the Natura 2000 network. Natura 2000 areas are specific habitats or landscapes that are selected for their biological diversity, and the presence of specific or threatened habitats and species. According to a plant diversity point of view, these habitats are also characterised by a particular phyto-sociological community [87].

\subsubsection{Specific species}

Biodiversity includes particular species in relationships with ecosystem processes. The literature has given several names to groups of species that are related to certain ecological functions. These different names may be cross-checked.

Indicator species are species which are used for many reasons such as an indirect measurement of the health of the ecosystem (condition indicator), identification of an area of high species richness (biodiversity indicator) or as markers of population size for other species (population/guild indicator) [68].

Keystone species have an important ecological function either in sustaining ecosystem functions or in sustaining populations of other species. For example, barrage building by beavers creates a wetland, while a cavity dug by a woodpecker may be used for nesting of other bird species. Keystone species are therefore precious tools for ecosystem conservation [125]. However, they are not the panacea. Not all ecosystems have keystone species. According to Bengtsson [9], ecosystem engineers (earthworm in the soil, Daphnia in the aquatic food web) are like keystone species.

Umbrella species are used to locate the edges of a conservation area. These are species that need a large area to survive. Conservation of this area provides protection for co-existing species.

Using terms such as focal species and surrogate species provoked a semantic and scientific polemic [3, 21]. However, focal species and surrogate species are sometimes used to designate indicator species or other particular species.

\subsubsection{Ecosystem processes and nutrient cycling}

Many studies [32, 33, 55, 67, 127, 128] have shown clearly that farming practices (fertilisation, pesticides and tillage) affect the population size and the dynamics of several groups (microbes, protozoa, vascular plants, nematodes, arthropods, annelids and vertebrates). In the face of biodiversity losses, ecologists have begun investigating this damage to ecosystem functioning. The relationship between diversity and ecosystem stability has been the most studied and debated since the 50s [78].

According to several authors [32, 33, 78], biodiversity is linked to ecosystem processes: matter, energy and nutrient cycles. Although these relationships are known, especially through the food web concept, their understanding is limited. The majority of studies and models are based on the relationship between diversity and stability (community and ecosystem process stability) $[71,76,79,137]$, but are often led on a single trophic level and on small scales.

Loreau et al. [78] supposed that the first theoretical studies applied the conventional wisdom (don't put all your eggs into one basket). In this vision, diversity of pathways provides stability. Below a threshold of biodiversity loss, stability is therefore broken and involves a cascade reaction of species loss, and the ecosystem is endangered. However, many results have shown that diversity is related to different stability properties. A greater diversity is not always favourable to community stability and process stability. One of the hypotheses about ecosystem functioning involves idiosyncratic process. Species make different contributions to ecosystems depending on certain conditions (e.g. community composition, etc.) [88].

Griffiths et al. [50,51] illustrated another complexity of ecosystem functioning: the redundancy of functional groups by a stress-on-stress experiment. The first stress is a disturbance applied to soil samples. It decreases the biodiversity but not all ecosystem processes. For example, organic matter decomposition may be greater than before the disturbance. At the second stress, the ecosystem processes decrease greatly. These experiments showed that the first stress has affected biodiversity stability while the second stress has affected process stability. Hence, ecosystem processes are not linked directly to biodiversity. As there is a functional redundancy in the soil community, a distinction must be observed between community and processes.

Loreau et al. [78] reviewed the different stability properties such as resilience or resistance. Resilience is "a measure of speed at which a system returns to [a stable] state after a perturbation", while resistance is "a measure of ability of a system to maintain its original state in the face of an external disruptive force". Resistance is the stability propriety of the ecosystem, for example, against invasion by non-native species.

Raffaelli et al. [116] suggested there was an urgent need to orient modelling on biogeochemical cycling and therefore research on a larger scale. "There have been very few attempts to explore the effect of biodiversity on the functioning of full ecosystems comprising higher trophic levels, decomposers and nutrient cycling and none as yet have considered stability explicitly" [78]. Ecological studies consider two ecosystem divisions: above-ground/below-ground, either plant-herbivore-predator or soil community. However, studies are often limited to small-scale soil- and plant-associated ecosystems (see, for example [33, 127]) and do not include mammals or birds. A multi-trophic approach is proposed to examine the ecosystem process holistically. 
Table I. Indices used for biodiversity description.

\begin{tabular}{|c|c|c|}
\hline Indices & Formula & Abbreviations \\
\hline 1 - Species richness $(\mathrm{S})$ & $\mathrm{S}=\mathrm{n}_{\mathrm{i}}$ & $\mathrm{n}_{\mathrm{i}}=$ species $\mathrm{i}$ \\
\hline $\begin{array}{l}2 \text { - Alpha diversity }\left(\mathrm{H}_{\alpha}{ }^{\prime}\right) \\
{[123]}\end{array}$ & $\mathrm{H}_{\alpha}{ }^{\prime}=\mathrm{p}_{\mathrm{i}} \log _{2} \mathrm{p}_{\mathrm{i}}$ & $\mathrm{p}_{\mathrm{i}}=$ frequency of the species $\mathrm{i}$ \\
\hline $\begin{array}{l}3 \text { - Beta diversity }\left(\mathrm{H}_{\beta}{ }^{\prime}\right) \\
{[145]}\end{array}$ & $\mathrm{H}_{\beta}{ }^{\prime}=\mathrm{S} / \mathrm{m}-1$ & $\begin{array}{c}\mathrm{S}=\text { species number (all samples) } \\
\mathrm{m}=\text { average number of species per sample }\end{array}$ \\
\hline $\begin{array}{l}4 \text { - Evenness }(\mathrm{J}) \\
{[113]}\end{array}$ & $\mathrm{E}=\mathrm{H}^{\prime} / \log _{2} \mathrm{~S}$ & \\
\hline $\begin{array}{l}5 \text { - Dominance (D) } \\
{[126]}\end{array}$ & $\mathrm{D}=\Sigma \mathrm{p}_{\mathrm{i}}^{2}$ & \\
\hline $\begin{array}{l}6 \text { - Rarity index }\left(\mathrm{I}_{\mathrm{R}}\right) \\
{[58,109]}\end{array}$ & $\mathrm{I}_{\mathrm{R}}=\Sigma \mathrm{C}_{\mathrm{i}} / \mathrm{S}$ & $\mathrm{C}_{\mathrm{i}}=$ rarity coefficient of the species $\mathrm{i}$ (from 1 to 13 ) \\
\hline
\end{tabular}

Many authors [71, 131, 137] have given information on the relationship between plant diversity and above-ground biomass of grassland. Biomass production is greater with species-rich communities than the most productive monoculture.

According to de Ruiter et al. [32], future research must focus on these links between biodiversity stability and process stability. Knowledge of these key properties will allow an understanding of the risks and effects of human disturbances.

\section{BIODIVERSITY ASSESSMENT}

Assessment tools are required to quantify and evaluate the impact of agricultural activities on biodiversity. Many methods have been proposed either by direct measurements on the site, or by indirect measurements. Biodiversity studies are generally focused on one scale: either on the habitat, patch, or landscape scale.

\subsection{Direct measurements of biodiversity}

\subsubsection{Simple indexes}

The biodiversity definition provided by the Convention on Biological Diversity takes composition (species, ecosystem, etc.) and structure (ecological process) into account. The taxonomic richness is the first biodiversity measurement which gives the number of taxa (family, genus, species, variety and ecotype) per unit area. This method is the most commonly used and represents the simplest expression of the diversity. Nevertheless, the value of this criterion used alone is limited as species number must be compared with a reference number for a particular habitat.

Diversity indices are another method that uses the number of taxa and their abundance (Tab. I). For example, communities which have the same number of species may differ in the abundance of each species.

The Shannon-Weaver index [123] (H) is the most commonly used index. It gives information on community complexity and can vary from 0 (one species alone) to $\log _{2} \mathrm{~S}$ (where all species have the same abundance). However, this index is not sensitive to strength variation. In the case of two ecosystems which have the same number of species, but one has twice as many indi- viduals as the other, the Shannon-Weaver Index gives the same value [115]. The Shannon-Weaver index is also used on a landscape scale to evaluate diversity of landscape elements [41, 89].The Shannon-Weaver index is used as an alpha-diversity index, because it gives information at species level.

Beta diversity could be defined as the difference in species composition between different communities. Beta diversity is larger when there are fewer common species between different communities [40]. The Whittaker index [145] could be the most suitable among the beta diversity indices available. This is partly because it is easy to calculate and interpret [148]. It can vary from 0 to 2 .

Gamma or regional diversity is the total number of species occurring in a system [81, 146].

The evenness $(\mathrm{J})$ [113] is a measure of abundance heterogeneity between species in a community. This parameter can vary from 0 to 1 . The maximum is obtained when all species have the same abundance in the study site. Evenness is calculated from Shannon-Weaver Index H.

Touzard and Clément [138] used another parameter to describe the diversity of the plant community: dominance. The dominance (D) is measured from the inverse of the Simpson diversity index [126]. When the dominance value is high, the study site contains species with high abundance.

Janssens [58] used another parameter: the rarity index, which is an important parameter for biodiversity conservation. The rarity index may be used to give the patrimonial value of a study site [109]. Peeters et al. [106] proposed vulnerability as a parameter which gives sensitivity of a taxon to extinction.

These different methods show that there are many diversity measures, but their suitability for use in different domains (soil microflora, arthropods, plants and landscape elements) is not always clear $[40,54,148]$.

\subsubsection{Biotic indicators}

Direct measurement of biological diversity is frequently used for biodiversity studies. However, this measurement is inconvenient due to high cost in terms of time and money, and the necessity for competence in species determination of very diverse organisms (soil arthropods, plants, birds, etc.). In addition, a sample represents a picture of biodiversity which changes all 
the time (day/night, weather, season, years). Thus, scientists have tried to find indirect or surrogate measurements to determine biodiversity. Instead of measure all the biodiversity, many scientists hold the view that the dynamics of taxa gives a picture of the dynamics of biodiversity $[34,36,37,64,65,68,80,107$, 108]. An important contribution on using biotic indicators was given in the special issue of Buchs [16]. Work of Duelli and Obrist [36] suggested arthropod higher taxa were better biotic indicators in terms of their ease of sampling and relationship with biodiversity. Assessment tools must be easily usable in order to be generalised for other case studies and to help decision-makers involved with land-use management.

\subsection{Evaluation of biodiversity functions by models}

\subsubsection{Modelling approaches considering live beings as dynamic systems}

Most of the models in ecology are based on a physical approach of individual organisms, populations or ecosystems. Live beings are not considered in all their complexity, but as dynamic systems which are determined by their state, as stated by physics [135]. For instance, it is the case of plant species competition models [49, 119]. Gounot's model is one of the first theoretical ecosystem models. It is based on compartments which correspond to elements of the grassland such as the cattle, the soil nutrients, the micro-organisms and the plant biomass. Matter and energy flows circulate between these compartments. Independent variables of the model are climate and grassland management. VEGPOP 2 is a recent model based on compartments, but it is operational thanks to the great improvement in scientific knowledge since the 1970s [119]. This model needs field experiments for plant species parameters concerning physiology, resource allocation, nitrogen flow, flowering or population dynamics (see Tab. II for details). VEGPOP 2 predicts the Shannon index, the plant biomass and the vegetation spatial dynamics [119]. Numerous other models are based on statistical analyses to quantify flows and compartments (for instance, see [6]). Three kinds of analyses can be distinguished: the classical linear regression models, the linear generalised relations, among which are the Gaussian, the binomial and the Poisson's distributions [150], and the generalised additive models. These models have up until now largely been used in ecology and they are well described elsewhere [52].

Besides these models, several models were inspired by the application of physics concepts. For instance, thermodynamics [151] or automatics [83] can help to predict structure, dynamics and functioning of ecosystems.

From the 1990s, the concomitance of the chaos theory, the account of interactions between ecosystems and the improvement of computer performance was at the origin of numerous individual-based models in ecology [63]. Now, numerous different models are available to explain or predict vegetation structure and dynamics of ecosystems [38, 66, 69, 77, 98, 111, 149]. None of these models evaluate the impact of farming practices on biodiversity, they only explain or predict vegetation structure or dynamics.

\subsubsection{Models predicting the threatening level of natural resources}

Potential impact models issued from German works of the 1970s on ecological risks [42]. Impact means the level from which resources and/or ecological functions are threatened by harmful use to the ecosystem's health. Potential means that not only are impact models in part based on field measurements, but they are limited by the available data and approximation inherent in modelling [42]. The model of Freyer et al. [42] predicts the level of natural resources threatened due to human activities such as pesticides and nitrogen inputs or mechanical action (e.g. ploughing). This model can be applied on various scales (see Tab. II for details).

\subsubsection{Models based on life traits}

Expert models are a novel modelling approach: they are based only on the knowledge of some traits or biological characteristics of animal or plant species. There is no need for statistical analyses or empirical relations to elaborate such models, but only field observation and biometric measurements to build a database. Once the database is built, expert models can predict very efficiently the species present in any ecosystem. These modelling approaches are the first concrete applications of functional groups theory based on life traits of plant species to predict animal or plant presence according to human activities and environmental factors [109].

For instance, Pervanchon [109] developed an expert model which predicts plant species' presence in any herbaceous ecosystem. This model is based on a database of 17 life traits or biological characteristics already identified in the literature for 2912 plant species. In order to predict the presence probability of grassland plant species, the information of the traits and characteristics are aggregated with data on farming practices and environment factors by fuzzy logic associated with an expert system. With such a model, it is possible to predict a list of plant species with their patrimonial value, without realising floristic sampling. The validation results of this model highlighted that it is only necessary to improve the knowledge on live plant traits to improve the expert models [109].

The use of species traits to predict the presence of species according to human activities and environment factors was also developed successfully to predict the presence of Syrphidae in any ecosystems [132]. If for plants, the scientific knowledge on biological traits still has big gaps, for Syrphidae, the traits are well detailed, and the lists of predicted species by the model and observed species in ecosystems are very similar.

\subsection{Surrogate measures of biodiversity: landscape metrics}

Ecologists have suspected for a long time that landscape composition and landscape pattern are highly significant for species diversity. However, the way in which species diversity behaves in landscapes with different spatial arrangements is largely unexplained [134].

One solution is to measure the elements that are related to biodiversity. Landscape parameters may be correlated with species diversity of many groups [60-62]. As a first step, a biodiversity 
Table II. Comparison between several models and indicators which evaluate the impact of agricultural practices on biodiversity and agronomic value of grasslands.

\begin{tabular}{|c|c|c|c|c|}
\hline Characteristics of the models & & Model of Freyer et al. (2000) & $\begin{array}{l}\text { VEGPOP2 } \\
\text { (Schippers \& Joenje, 2002) }\end{array}$ & Model of Pervanchon, 2004 \\
\hline Model type & & Potential impact model & Vegetation dynamic model & $\begin{array}{l}\text { Expert based model associated } \\
\text { with fuzzy logic }\end{array}$ \\
\hline Model objectives & & $\begin{array}{l}\text { Evaluation of human activities } \\
\text { impacts on ecological functions }\end{array}$ & $\begin{array}{l}\text { Evaluation of human activities' } \\
\text { impacts on plant diversity } \\
\text { (biomass, Shannon Index) }\end{array}$ & $\begin{array}{l}\text { Evaluation of human activities' } \\
\text { impacts on ecological and } \\
\text { agronomic function of any kind } \\
\text { of herbaceous surfaces }\end{array}$ \\
\hline Targeted users & & Unknown & Unknown & $\begin{array}{l}\text { Agricultural development } \\
\text { managers }\end{array}$ \\
\hline \multicolumn{5}{|l|}{ Model structure } \\
\hline \multirow[t]{3}{*}{ Parameters } & $\begin{array}{l}\text { Human activities } \\
\text { Environment } \\
\text { characteristics } \\
\text { Studied species }\end{array}$ & $\begin{array}{l}\text { Pesticide inputs, ploughing, } \\
\text { drainage, proportion of the } \\
\text { different activities on a } \\
\text { landscape scale }\end{array}$ & $\begin{array}{l}\text { Hay cutting, } \mathrm{N} \text { fertilisation, } \\
\text { herbicides }\end{array}$ & $\begin{array}{l}\text { Hay cutting, grazing, water } \\
\text { management (drainage, } \\
\text { irrigation), } \mathrm{N} \text { and } \mathrm{P} \text { fertilisation, } \\
\text { calcareous inputs }\end{array}$ \\
\hline & & $\begin{array}{l}\text { Groundwater, soil, climate, } \\
\text { species, biotopes, landscape } \\
\text { and amenities. }\end{array}$ & Field perimeter & $\begin{array}{l}\text { Corine habitat, } \mathrm{N} \text { and } \mathrm{P} \text { soil } \\
\text { fertility, soil depth, } \mathrm{pH} \text {, soil } \\
\text { moisture, temperature }\end{array}$ \\
\hline & & $\begin{array}{l}\text { Unknown: species and biotopes } \\
\text { are together in the frame of } \\
\text { "environment protection". }\end{array}$ & $\begin{array}{l}\text { Parameterisation for } 4 \text { plant } \\
\text { species (Poa annua, Holcus } \\
\text { lanatus, Anthoxantum odoratum, } \\
\text { Festuca ovina tenuifolia) }\end{array}$ & 2912 European plant species \\
\hline Model outputs & & $\begin{array}{l}\text { Potential impact of human } \\
\text { activities on resources }\end{array}$ & Shannon index, plant biomass & $\begin{array}{l}\text { Plant species lists (names) } \\
\text { according to agricultural } \\
\text { practices }\end{array}$ \\
\hline Input data & & $\begin{array}{l}\text { Measured data, maps, statistical } \\
\text { data }\end{array}$ & $\begin{array}{l}\text { Fertilisation and disturbance } \\
\text { levels }\end{array}$ & Data given by farmers and maps \\
\hline Scale & & $\begin{array}{l}\text { Landscape, field, biotope or } \\
\text { species }\end{array}$ & Field boundary & $\begin{array}{l}\text { Herbaceous surface } \\
\text { (e.g.: grassland) }\end{array}$ \\
\hline \multicolumn{5}{|l|}{ Calculation methodology } \\
\hline Statistical analysis & & None & $\begin{array}{l}\text { Yes: relations for spatial } \\
\text { representation of plant } \\
\text { competition }\end{array}$ & None \\
\hline Fuzzy logic & & $\begin{array}{l}\text { Yes: exponential, logarithmic, } \\
\text { multilinear and linear functions }\end{array}$ & None & Equivalent of sigmoid functions \\
\hline \multirow[t]{2}{*}{ Other methods } & Type of equation & $\begin{array}{l}\text { Ratio and average of weighted } \\
\text { parameters. }\end{array}$ & None & $\begin{array}{l}\text { Choice of the minimum: plant } \\
\text { species presence probability is } \\
\text { the minimum of the all } \\
\text { probabilities. }\end{array}$ \\
\hline & Justification & None & 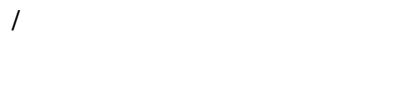 & $\begin{array}{l}\text { Precaution principle and limiting } \\
\text { factor theory }\end{array}$ \\
\hline Application area & & Various biotopes or landscapes & $\begin{array}{l}\text { Areas where the } 4 \text { species are } \\
\text { parameterised }\end{array}$ & 4 French Regional Natural Parks \\
\hline Model generalisation & & Unknown & Unknown & $\begin{array}{l}\text { Any herbaceous surfaces where } \\
\text { some of the } 2912 \text { species are } \\
\text { potentially present }\end{array}$ \\
\hline Validation & & Unknown & $\begin{array}{l}\text { Satisfying results for some parts } \\
\text { of the model }\end{array}$ & $\begin{array}{l}\text { Satisfying results for French } \\
\text { permanent grasslands; not tested } \\
\text { for other surfaces }\end{array}$ \\
\hline Computerised version & & yes & yes & yes \\
\hline
\end{tabular}

parameter is studied in relation to spatial information. For example, data are searched for on the presence of a target species in different habitats. After determining the link between the abundance of the species and spatial structure, this link is modelled and then validated. In the end, landscape data are only necessary for monitoring the target species. Currently, a higher 
diversity level on the landscape scale is used to predict a lower diversity level (species richness, etc.) [60], and even if biodiversity is linked to landscape parameters, there are no general models.

For this reason, very many indicators based on spatial information have been built. Piorr [114] reviewed agri-environmental indicators and landscape indicators used in the European Union.

The OECD produced agri-environmental indicators which were adjusted to the driving force-state-response (DSR) framework [94-96]. DSR indicators focus on the causes of change in environmental conditions in an agriculture area, the effects of agriculture on the environment and the efficiency of any actions taken.

The OECD Expert Meeting, May 1999, in Paris suggested more concrete indicators [86]. One goal was to select relevant landscape indicators for the data available. An example for EU territory monitoring is the Corine Land Cover (CLC) [28]. This monitoring at the EU level allows determination of anthropogenic impacts on landscapes. Initiatives aiming to preserve the quality of landscapes can be designated. However, at the EU level monitoring is limited. A specific level must be chosen and the data are of limited significance for specific analysis.

The European Community initiated a project proposal on agri-environmental indicators called the PAIS project. This project contained indicators within the domain of landscapes, rural development and agricultural practices which were applicable at EU level. Thirty-six landscape indicators were chosen as relevant. At the moment these landscape indicators cannot give answers regarding biodiversity. Future steps will be to determine the relevant landscape indicators that are related to biodiversity and nature protection purposes [114].

In order to follow landscape development, several European countries have produced landscape conservation schemes and landscape indicators. These monitoring programmes have helped in the planning and delimitation of nature conservation areas.

Peeters et al. [106] reviewed a list of direct indicators (specific biotic indicators, natural area rate, etc.) and indirect indicators (rate of areas with a high slope, fertiliser quantity, etc.) to promote sustainable management of grasslands. However, these indicators can give answers which are contradictory and frequently do not facilitate decision-making.

\subsection{Agro-ecological indicators}

Girardin et al. [46] adopted the interaction matrix [72] for an environmental impact assessment methodology. This method evaluates the effects of farm production practices on different components of the agro-ecosystem. Evaluation modules, which characterise the impact of a production practice on an environmental component, can be aggregated to yield two types of indicators. Agro-ecological indicators reflect the impact of one production practice on all environmental components concerned, while indicators of environmental impact reflect the impact of all production practices concerned on one environmental component [140].

Pervanchon [110] proposed a methodology to evaluate the impact of agricultural practices on grassland biodiversity. Agro- ecological indicators are predictive tools and help with decision-making. These indicators use easily accessible data that can be collected by non-specialists However, the building of indicators is dependent on scientific knowledge and indicators are only suitable if they are validated for sensitivity and usability value [47].

\section{CONCLUSION}

Functional vision is an operational approach which permits clarification of the complex concept of biodiversity. Biodiversity is too large to be entirely assessed by a single criterion. Biological diversity must therefore be evaluated according to precise objectives: ecological, agronomical or patrimonial approaches. Many tools have been built to assess biodiversity but they measure only some parts of biodiversity. For example, models are often limited to simple systems, while validation of indicators shows the complexity of these systems. Future studies ought to examine understanding of the relationships between biodiversity and agro-ecosystems with complementary approaches (agronomy and ecology) and produce suitable tools that permit decision-making. Studies frequently examine only one scale whereas these relationships are relevant on different scales and are interconnected.

\section{REFERENCES}

[1] Alabouvette C., Backhouse D., Steinberg C., Donovan N.J., EdelHermann V., Burgess L.W., Microbial diversity in soil - effects on crop health, in: Managing soil quality: challenges in modern agriculture, Schjonning P., Elmholt S., Christensen B.T. (Eds.), CABI Publishing, Wallingford, UK, 2004, pp. 121-138.

[2] Altieri M.A., The ecological role of biodiversity in agroecosystems, Agr. Ecosyst. Environ. 74 (1999) 19-31.

[3] Armstrong D., Focal and surrogates species: getting the language right, Conserv. Biol. 16 (2002) 285-286.

[4] Arriaza M., Canas-Ortega J.F., Canas-Madueno J.A., Ruiz-Aviles P., Assessing the visual quality of rural landscapes, Landscape Urban Plan. 69 (2004) 115-125.

[5] Arthur L.M., Daniel T.C., Boster R.S., Scenic assessment: an overview, Landscape Urban Plan. 4 (1977) 109-129.

[6] Bai Y., Abouguendia Z., Redmann R.E., Relationship between plant species diversity and grassland condition, J. Range Manage. 54 (2001) 177-183.

[7] Barron M., Wratten S.D., B.J.D., A four year investigation into efficacy of domiciles for enhancement of bumblebee populations, Agr. Forest Entomol. 2 (2000) 141-146.

[8] Bataillon T., Bonnin I., David J. et al., Understanding dynamics of genetic diversity in highly selfing plant populations: experimental insights from Arabidopsis thaliana, Medicago truncata and Triticum durum, $4^{\mathrm{e}}$ Colloque National, Genetic inheritance: the diversity and the resource, La Châtre, 2003.

[9] Bengtsson J., Which species? What kind of diversity? Which ecosystem function? Some problems in studies of relations between biodiversity and ecosystem function, Appl. Soil Ecol. 10 (1998) 191-199.

[10] Bootsma M.C., Barendregt A., van Alphen J.C.A., Effectiveness of reducing external nutrient load entering a eutrophicated shallow lake ecosystem in the Naardermeer nature reserve, The Netherlands, Biol. Conserv. 90 (1999) 193-201. 
[11] Bosshard A., What does objectivity mean for analysis, valuation and implementation in agricultural landscape planning? A practical and epistemological approach to the search for sustainability in 'agriculture'*1, Agr. Ecosyst. Environ. 63 (1997) 133-143.

[12] Breuste J.H., Decision making, planning and design for the conservation of indigenous vegetation within urban development, Landscape Urban Plan. 68 (2004) 439-452.

[13] Briggs D.J., France J., Landscape evaluation: a comparative study, J. Environ. Manage. 10 (1980) 263-275.

[14] Brundtland G., Our common future, in: World Commision on Environment and Development, 1987.

[15] Buchin S., Martin B., Dupont D., Bornard A., Achilleos C., Influence of the composition of Alpine highland pasture on the chemical, rheological and sensory properties of cheese, J. Dairy Res. 66 (1999) 579-588.

[16] Buchs W., Biotic indicators for biodiversity and sustainable agriculture-introduction and background, Agr. Ecosyst. Environ. 98 (2003) 1-16

[17] Buchs W., Biodiversity and agri-environmental indicators-general scopes and skills with special reference to the habitat level, Agr. Ecosyst. Environ. 98 (2003) 35-78.

[18] Burel F., Baudry J., Écologie du paysage : concepts, méthodes et applications, Éditions Tec \& Doc, Paris, 1999.

[19] Burel F., Baudry J., Species diversity in changing agricultural landscapes: a case study in the Pays d'Auge, France, Agr. Ecosyst. Environ. 55 (1995) 193-200.

[20] Cairns J., Defining goals and conditions for a sustainable world, Environ. Health Persp. 105 (1997) 1164-1170.

[21] Caro T., Focal species, Conserv. Biol. 14 (2000) 1569-1570.

[22] Carpino S., Mallia S., La Terra S. et al., Composition and aroma compounds of Ragusano cheese: native pasture and total mixed rations, J. Dairy Sci. 87 (2004) 816-830.

[23] CBD, 1992

http://www.biodiv.org/convention/articles.asp?lg=0\&a=cbd-07

[24] CBD, 1992, http://www.biodiv.org/convention/articles.asp

[25] Chiarucci A., Maccherini S., De Dominicis V., Evaluation and monitoring of the flora in a nature reserve by estimation methods, Biol. Conserv. 101 (2001) 305-314

[26] CNRS, Les Bocages : histoire, écologie, économie, in: Rennes : Table ronde CNRS "Aspects physiques, biologiques et humains des écosystèmes bocagers des régions tempérées humides" INRA, ENSA and Université de Rennes, 1976, 586.

[27] Colquhoun M., An exploration into the use of Goethean science as a methodology for landscape assessment: the Pishwanton Project, Agr. Ecosyst. Environ. 63 (1997) 145-157.

[28] CORINE-Land-Cover, 2000, http://europa.eu.int/comm/agriculture/publi/landscape/index.htm

[29] Cornu A., Carnat A.-P., Martin B., Coulon J.-B., Lamaison J.-L., Berdagué J.-L., Solid-Phase Microextraction of volatile components from natural grassland plants, J. Agr. Food Chem. 49 (2001) 203-209.

[30] Crossley J.D.A., Coleman D.C., Hendrix P.F., The importance of the fauna in agricultural soils: Research approaches and perspectives, Agr. Ecosyst. Environ. 27 (1989) 47-55.

[31] De Rochambeau H., Verrier E., Bidanel J. et al., Implementation of tools to describe the genetic variability in selected animal domectic populations and drawing up management rules: practical application to milking sheep and to pig breeds, $4^{\mathrm{e}}$ Colloque National, Genetic inheritance: the diversity and the resource, La Châtre, 2003.
[32] de Ruiter P., Griffiths B., Moore J., Biodiversity and stability in soil ecosystems: patterns, processes and the effects of disturbance, in: Biodiversity and Ecosystem Functioning: Synthesis and Perspectives, Loreau M.N.S., Inchausti P. (Eds.), Oxford University Press, Oxford, 2002, pp. 102-113.

[33] de Ruiter P., Neutel A.-M., Moore J., Modelling food webs and nutrient cycling in agro-ecosystems, Trends Ecol. Evol. 9 (1994) 283-378.

[34] Doring T.F., Hiller A., Wehke S., Schulte G., Broll G., Biotic indicators of carabid species richness on organically and conventionally managed arable fields, Agr. Ecosyst. Environ. 98 (2003) 133139.

[35] Dorioz J.-M., Fleury P., Coulon J.-B., Martin B., La composante milieu physique dans l'effet terroi pour la production fromagère : quelques réflexions à partir du cas des fromages des Alpes du Nord, Courrier de l'environnement de l'INRA 2000, Juin 2000, pp. 47-55.

[36] Duelli P., Obrist M.K., in search of the best correlates for local organismal biodiversity in cultivated areas, Biodivers. Conserv. 7 (1998) 297-309.

[37] Duelli P., Obrist M.K., Biodiversity indicators: the choice of values and measures, Agr. Ecosyst. Environ. 98 (2003) 87-98.

[38] Ejrnaes R., Bruun H.H., Gradient analysis of dry grassland vegetation in Denmark, J. Veg. Sci. 11 (2000) 573-584.

[39] Europe Co, 2000, http://www.coe.int/t/e/Cultural_Co-operation/ Environment/Landscape/

[40] Fang W., Peng S.L., Development of species diversity in the restoration process of establishing a tropical man-made forest ecosystem in China, Forest Ecol. Manage. 99 (1997) 185-196.

[41] Forman R., Land mosaics: the ecology of landscapes and regions, Cambridge University Press, Cambridge, 1995.

[42] Freyer B., Reisner Y., Zuberbühler D., Potential impact model to assess agricultural pressure to landscape ecological functions, Ecol. Model. 130 (2000) 121-129.

[43] Fustec E., Lefeuvre J.-C., Fonctions et valeurs des zones humides, Dunod, Paris, 2000

[44] Gaston K., Biodiversity, A Biology of Numbers and Difference, London, UK, 1996.

[45] Gerber S., Latouche-Hallé C., Lourmas M. et al., Direct measures of gene flow in forest, $4^{\mathrm{e}}$ Colloque National, Genetic inheritance: the diversity and the resource, La Châtre, 2003.

[46] Girardin P., Bockstaller C., Van der Werf H., Evaluation of relationship between the environment and agricultural practices - the AGRO-ECO method, Environ. Impact Assess. Rev. 20 (2000) 227-239.

[47] Girardin P., Bockstaller C., Van der Werf H., Indicators: tools to evaluate the environmental impacts of farming systems, J. Sustain. Agr. 13 (1999) 5-21.

[48] Giraudoux P., Delattre P., Habert M. et al., Population dynamics of fossorial water vole (Arvicola terrestris scherman): a land use and landscape perspective, Agr. Ecosyst. Environ. 66 (1997) $47-$ 60.

[49] Gounot M., Méthodes d'études et d'inventaire de la végétation pastorale et prairiale, Fourrages 4 (1960) 46-52.

[50] Griffiths Bea, Ecosystem response of pasture soil communities to fumigation-induced microbial diversity reductions: an examination of the biodiversity-ecosystem function relationship, Oikos 90 (2000) 279-294.

[51] Griffiths Bea, An examination of the biodiversity-ecosystem function relationship in arable soil microbial communities, Soil Biol. Biochem. 33 (2001) 1713-1722. 
[52] Guisan A., Edwards T.C. Jr., Hastie T., Generalized linear and generalized additive models in studies of species distributions: setting the scene, Ecol. Model. 157 (2002) 89-100.

[53] Gurr G.M., Wratten S.D., Luna J.M., Multifunction agricultural biodiversity: pest management and other benefits, Basic Appl. Ecol. 4 (2003) 107-116

[54] Hill T.C.J., Walsh K.A., Harris J.A., Moffett B.F., Using ecological diversity measures with bacterial communities, FEMS Microbiol. Ecol. 43 (2003) 1-11.

[55] Hinsley S.A., Bellamy P.E., The influence of hedge structure, management and landscape context on the value of hedgerows to birds: A review, J. Environ. Manage. 60 (2000) 33-49.

[56] IFEN, DATAR, l'Environnement MdlAdted, Aménagement du territoire et environnement : politiques et indicateurs, IFEN, 2000.

[57] Jackson L.F., Wennig R.W., Use of wheat cultivar blends to improve grain yield and quality and reduce disease and lodging, Field Crop Res. 52 (1997) 261-269.

[58] Janssens F., Restauration des couverts herbacés riches en espèces, $\mathrm{Ph} . \mathrm{D}$. Thesis, Louvain-la-Neuve, Université catholique de Louvain, 1998, 135.

[59] Jeangros B., Troxler J., Conod D. et al., Étude des relations entre les caractéristiques des herbages et celles du lait, de la crème et du fromage de type L'Étivaz ou Gruyère, Rev. Suisse Agr. 29 (1997) $23-34$.

[60] Jeanneret P., Schupbach B., Luka H., Quantifying the impact of landscape and habitat features on biodiversity in cultivated landscapes, Agr. Ecosyst. Environ. 98 (2003) 311-320.

[61] Jeanneret P., Schüpbach B., Pfiffner L., Herzog F., Walter T., The swiss agri-environmental programme and its effect on selected biodiversity indicators, J. Nat. Conserv. 11 (2003) 213-220.

[62] Jeanneret P., Schüpbach B., Pfiffner L., Walter T., Arthropod reaction to landscape and habitat features in agricultural landscapes, Landscape Ecol. 18 (2003) 253-263.

[63] Judson O.P., The rise of the individual-based model in ecology, Trends Ecol. Evol. 9 (1994) 9-14.

[64] Kati V., Devillers P., Dufrene M., Legakis A., Vokou D., Lebrun P., Hotspots, complementarity or representativeness? designing optimal small-scale reserves for biodiversity conservation, Biol. Conserv. 120 (2004) 471-480.

[65] Kati V., Devillers P., Dufrene M., Legakis A., Vokou D., Lebrun $\mathrm{P} .$, Testing the value of six taxonomic groups as biodiversity indicators at a local scale, Conserv. Biol. 18 (2002) 667-675.

[66] Koleff P., Gaston K.J., Latitudinal gradients in diversity: real patterns and random models, Ecography 24 (2001) 341-351.

[67] Kromp B., Carabid beetles in sustainable agriculture: a review on pest control efficacy, cultivation impacts and enhancement, Agr. Ecosyst. Environ. 74 (1999) 187-228.

[68] Landres P.B., Verner J.W.T.J., Ecological uses of vertebrate indicator species: a critique, Conserv. Biol. 2 (1988) 316-328.

[69] Laterra P., Solbrig O.T., Dispersal strategies, spatial heterogeneity and colonization success in fire-managed grasslands, Ecol. Model. 139 (2001) 17-29.

[70] Lefeuvre J.-C., Laffaille P., Feunteun E., Bouchard V., Radureau A., Biodiversity in salt marshes: from patrimonial value to ecosystem functioning. The case study of the Mont-Saint-Michel bay, C.R. Biol. 326 (2003) 125-131.

[71] Lehman C., Tilman D., Biodiversity, stability, and productivity in competitive communities, Am. Nat. 156 (2000) 534-552.

[72] Leopold L., Clarke F., Hanshaw B., Balsley J., A procedure for evaluating environment impact. Geographical Survey Circular 645, in: Washington: United States Department of Interior, 1971, pp. $1-13$.
[73] Levine J., Kennedy T., Naeem S., Neighbourhood scale effects of species diversity on biological invasions and their relationship to community pattern, in: Biodiversity and Ecosystem Functioning: Synthesis and Perspectives, Loreau M.N.S., Inchausti P. (Eds.), Oxford University Press, Oxford, 2002, pp. 114-124.

[74] Lofvenhaft K., Runborg S., Sjogren-Gulve P., Biotope patterns and amphibian distribution as assessment tools in urban landscape planning, Landscape Urban Plan. 68 (2004) 403-427.

[75] Lomolino M.V., An evaluation of alternative strategies for building networks of nature reserves, Biol. Conserv. 69 (1994) 243 249.

[76] Loreau M., Biodiversity and ecosystem functioning: recent theorical advances, Oikos 91 (2000) 3-17.

[77] Loreau M., Biodiversity and ecosystem functioning: a mechanistic model, Proceedings of the National Academy of Sciences of the United States of America, 1998

[78] Loreau M., Downing A., Emmerson M. et al., A new look at the relationship between diversity and stability, in: Biodiversity and Ecosystem Functioning: Synthesis and Perspectives, Loreau M.N.S., Inchausti P. (Eds.), Oxford University Press, Oxford, 2002, pp. 79-91.

[79] Loreau M., Biodiversity and ecosystem functioning: curren knowledge and future challenges, Science 294 (2001) 804-808.

[80] Mac Nally R., Fleishman E., A successful predictive model of species richness based on indicator species, Biol. Conserv. 18 (2004) 646-654.

[81] Maguran A., Ecological Diversity and its Measurements, Princeton University Press, Princeton, 1988.

[82] Mariaca R., Berger T., Gauch R., Imhof M., Jeangros B., Bosset J., Occurence of Volatile Mono and Sesquiterpenoids in Highland and Lowland Plant Species as Possible Precursors for Flavor Compounds in Milk and Dairy Products, J. Agr. Food Chem. 45 (1997) 4423-4434.

[83] Matsinos Y.G., Troumbis A.Y., Modeling competition dispersal and effects of disturbance in the dynamics of a grassland community using a cellular automaton model, Ecol. Model. (2002) in press.

[84] Millán de la Peña N., Butet A., Delettre Y. et al., Response of the small mammal community to changes in western French agricultural landscapes, Landscape Ecol. 18 (2003) 265-278.

[85] Mineau P., McLachlin A., Conservation of biodiversity within Canadian agricultural landscapes: integrating habitat for wildlife, J. Agr. Environ. Ethic. 9 (1996) 93-113.

[86] Morard V., Vidal C., Eiden G. et al., Landscape indicators. OECDRoom Document No. 3, in: Paris: OECD Expert Meeting on Biodiversity. Wildlife Habitat and Landscape, 1999.

[87] Muller S., Appropriate agricultural management practices required to ensure conservation and biodiversity of environmentally sensitive grassland sites designated under Natura 2000, Agr. Ecosyst. Environ. 89 (2002) 261-266.

[88] Naeem S., Loreau M., Inchausti P., Biodiversity and ecosystem functioning: the emergence of a ecological framework, in: Biodiversity and Ecosystem Functioning: Synthesis and Perspectives, Loreau M.N.S., Inchausti P. (Eds.), Oxford University Press, Oxford, 2002, pp. 3-11.

[89] Nagendra H., Opposite trends in response for the Shannon and Simpson indices of landscape diversity, Appl. Geogr. 22 (2002) 175-186.

[90] Nelson E., Biological control of turfgrass diseases, in: Advances in plant disease management, Huang H.C., Acharya S.N. (Eds.), Research Signpost, Trivandrum, India, 2003, pp. 19-51. 
[91] Nohl W., Sustainable landscape use and aesthetic perception-preliminary reflections on future landscape aesthetics, Landscape Urban Plan. 54 (2001) 223-237.

[92] Noss R.F., Indicators for monitoring biodiversity: a hierarchical approach, Conserv. Biol. 4 (1990) 355-364.

[93] Odum E., Fundamentals of ecology, 3rd ed. Saunders, Philadelphie, 1971.

[94] OECD, Environmental Indicators for Agriculture, Vol. 1: Concepts and Framework, in: Paris: Publications Service, OECD, 1997.

[95] OECD, Environmental Indicators for Agriculture, Vol. 2: Issues and Design - The York Workshop, in: Paris: Publications Service, OECD, 1999.

[96] OECD, Environmental Indicators for Agriculture, Vol. 3: Methods and Results, in: Paris: Publications Service, OECD, 2001.

[97] Oldfield T.E.E., Smith R.J., Harrop S.R., Leader-Williams N., A gap analysis of terrestrial protected areas in England and its implications for conservation policy, Biol. Conserv. 120 (2004) 303-309.

[98] Pacala S.W., Crawley M.J., Herbivores and plant diversity, Am. Nat. 140 (1992) 243-260.

[99] Palmer J.F., Using spatial metrics to predict scenic perception in a changing landscape: Dennis, Massachusetts, Landscape Urban Plan. 69 (2004) 201-218.

[100] Palmer J.F., Stability of landscape perceptions in the face of landscape change, Landscape Urban Plan. 37 (1997) 109-113.

[101] Paoletti M.G., Biodiversity, traditional landscapes and agroecosystem management, Landscape Urban Plan. 31 (1995) 117-128.

[102] Paoletti M.G., Pimentel D., Stinner B.R., Stinner D., Agroecosystem biodiversity: matching production and conservation biology, Agr. Ecosyst. Environ. 40 (1992) 3-23.

[103] Partel M., Helm A., Ingerpuu N., Reier U., Tuvi E.-L., Conservation of Northern European plant diversity: the correspondence with soil pH, Biol. Conserv. 120 (2004) 525-531.

[104] Pasche F., Armand M., Gouaux P., Lamaze T., Pornon A., Are meadows with high ecological and patrimonial value endangered by heathland invasion in the French central Pyrenees? Biol. Conserv. 118 (2004) 101-108.

[105] Peeters A., Janssens F., Agriculture et nature, concilier la biodiversité et une production agricole performante en prairie : est-ce possible? Ann. Gembloux 101 (1995) 127-147.

[106] Peeters A., Maljean J., Biala K., Brouckaer V., Les indicateurs de biodiversité en prairie : un outil d'évaluation de la durabilité des systèmes d'élevage, La biodiversité des prairies : un patrimoine un rôle fonctionnel, Paris, 23-24 mars 2004.

[107] Perner J., Sample size and quality of indication - a case study using ground-dwelling arthropods as indicators in agricultural ecosystems, Agr. Ecosyst. Environ. 98 (2003) 125-132.

[108] Perner J., Malt S., Assessment of changing agricultural land use: response of vegetation, ground-dwelling spiders and beetles to the conversion of arable land into grassland, Agr. Ecosyst. Environ. 98 (2003) 169-181.

[109] Pervanchon F., Modélisation de l'effet des pratiques agricoles sur la diversité végétale et la valeur agronomique des prairies permanentes en vue de l'élaboration d'indicateurs agri-environnementaux, Ph.D. Thesis, Nancy, INPL, 2004.

[110] Pervanchon F., Bahmani I., Plantureux S., Girardin P., A methodology to evaluate the impact of agricultural practices on grassland biodiversity, Multi-fonction grassland: quality forages, animal products and landscapes 19th General Meeting of the European Grassland Federation, La Rochelle, 2002.
[111] Peters D.P.C., Plant species dominance at a grassland-shrubland ecotone: an individual-based gap dynamics model of herbaceaous and woody species, Ecol. Model. 152 (2002) 5-32.

[112] Petrarca, http://www.petrarca.info

[113] Pielou E., The measures of diversity in different types of biological collections, J. Theor. Biol. 13 (1966) 131-144.

[114] Piorr H.-P., Environmental policy, agri-environmental indicators and landscape indicators, Agr. Ecosyst. Environ. 98 (2003) 17-33.

[115] Pitkänen S., The use of diversity indices to assess the diversity of vegetation in boreal forests, Forest Ecol. Manage. 112 (1998) 121-137.

[116] Raffaelli D., Van der Putten W., Persson L. et al., Multi-trophic dynamics and ecosystem processe, in: Biodiversity and Ecosystem Functioning: Synthesis and Perspectives, Loreau M.N.S., Inchausti P. (Eds.), Oxford University Press, Oxford, 2002, pp. 147-154.

[117] Reeleder R., Fungal plant pathogens and soil biodiversity, Can. J. Soil Sci. 83 (2003) 331-336.

[118] Ruellan A., Caractérisation physique des bocages : rapport de synthèse, in: Rennes : Tables rondes "Écosystèmes bocagers", 1976, pp. 145-151.

[119] Schippers P., Joenje W., Modelling the effect of fertiliser, mowing, disturbance and width on the biodiversity of plant communities of field boundaries, Agr. Ecosyst. Environ. 93 (2002) 351365 .

[120] Schläpfer F., Expert estimates about effects of biodiversity on ecosystem processes and services, Oikos 82 (1999) 346-352.

[121] Schüpbach B., Methods for indicators to assess landscape aesthetic, in: Agricultural impact on landscapes: Developing indicators for policy analysis: NIJOS, 2003, pp. 277-288.

[122] Shafer E.L., Hamilton J.F., Schmidt E.A., Natural landscape preferences: a predictive model, J. Leisesure Res. 1 (1969) 1-19.

[123] Shannon C., Weaver W., The mathematical theory of communication, University of Illinois Press, Urbana, Illinois, 1949.

[124] Shea K., Chesson P., Community ecology theory as a framework for biological invasions, Trends Ecol. Evol. 17 (2002) 170-176.

[125] Simberloff D., Flagships, umbrellas, and keystones: Is single-species management passe in the landscape era? Biol. Conserv. 83 (1998) 247-257.

[126] Simpson E., Measure of diversity, Nature 163 (1949) 688

[127] Smeding F.W., de Snoo G.R., A concept of food-web structure in organic arable farming systems, Landscape Urban Plan. 65 (2003) 219-236.

[128] Smeding F.W., Joenje W., Farm-Nature Plan: landscape ecology based farm planning, Landscape Urban Plan. 46 (1999) 109-115.

[129] Soltner D., L'arbre et la haie, pour la production agricole, pour l'équilibre écologique et le cadre de vie rurale, Saint Gemmes sur Loire, 1973.

[130] SOS-Arvel, http://www.sos-arvel.ch

[131] Spehn E., Joshi J., Schmid B., Diemer M., Körner C., Above-ground resource use increases with plant species richness in experimental grassland ecosystems, Funct. Ecol. 14 (2000) 326-337.

[132] Speight M.C.D., Castella E., An approach to interpretation of lists of insects using digitised biological information about the species, J. Insect Conserv. 5 (2001) 131-139.

[133] Steiner F., The Living Landscape: An Ecological Approach to Landscape Planning, McGraw-Hill, New York, 1991.

[134] Steiner N.C., Kohler W., Effects of landscape patterns on species richness - a modelling approach, Agr. Ecosyst. Environ. 98 (2003) 353-361. 
[135] Stewart J., La modélisation en biologie, in: Enquête sur le concept de modèle, Nouvel P. (Ed.), Presses Universitaires de France, Paris, France, 2002, pp. 43-66.

[136] Strullu D.-G., Les Mycorhizes, Handbuch des Pflanzenanatomie, Berlin, 1985.

[137] Tilman D., The ecological consequences of changes in biodiversity: a search for general princiles, Ecol. 80 (1999) 1455-1474.

[138] Touzard B., Clément B., Effets de microperturbations expérimentales sur la dynamique de la diversité végétale d'une roselière alluviale eutrophe, Bot. Helv. 111 (2001) 45-58.

[139] Vaillon C., Martin B., Verdier-Metz I. et al., Transfer of monoterpenes and sesquiterpenes from forage into milk fat, Lait 80 (2000) 635-641.

[140] van der Werf H.M.G., Petit J., Evaluation of the environmental impact of agriculture at the farm level: a comparison and analysis of 12 indicator-based methods, Agr. Ecosyst. Environ. 93 (2002) 131-145.

[141] Vereijken J.F.H.M., van Gelder T., Baars T., Nature and landscape development on organic farms, Agr. Ecosyst. Environ. 63 (1997) 201-220.

[142] Walker B., Kinzig A., Langridge J., Plant attribute diversity, resilience, and ecosystem function: the nature and significance of dominant and minor species, Ecosystems 2 (1999) 95-113.
[143] Weinstoerffer J., Girardin P., Assessment of the contribution of land use pattern and intensity to landscape quality: use of a landscape indicator, Ecol. Model. 130 (2000) 95-109.

[144] White J.G., Antos M.J., Fitzsimons J.A., Palmer G.C., Non-uniform bird assemblages in urban environments: the influence of streetscape vegetation, Landscape Urban Plan., in press.

[145] Whittaker R.H., Evolution and measurement of species diversity, Taxon 21 (1972) 213-251.

[146] Whittaker R.H., Communities and Ecosystems, MacMillan, New York, 1975.

[147] Widmer T.L.M.N.A., Abawi G.S., Soil organic matter and management of plant-parasitic nematodes, J. Nematol. 34 (2002) 289295.

[148] Wilson M.V., Shmida A., Measuring beta diversity with presenceabsence data, J. Ecol. 72 (1984) 1055-1064.

[149] Wilson W.L., Abernethy V.J., Murphy K.J. et al., Prediction of plant diversity response to land-use change on Scottish agricultural land, Agr. Ecosyst. Environ. 1965 (2002) 1-15.

[150] Yee T., Mitchell N.D., Generalized additive models in plant ecology, J. Veg. Sci. 2 (1991) 587-602.

[151] Zhang H., Wu J., A statistical thermodynamic model of the organizational order of vegetation, Ecol. Model. (2002) in press. 